\title{
THE PHYSIOLOGICAL SIGNIFICANCE OF THE SECRETION OF ENDOGENOUS INSULIN INTO THE PORTAL CIRCULATION. III. EVIDENCE FOR A DIRECT IMMEDIATE EFFECT OF INSULIN ON THE BALANCE OF GLUCOSE ACROSS THE LIVER * $\dagger$
}

\author{
BY LEONARD L. MADISON, BURTON COMBES, $\ddagger$ REUBEN ADAMS AND \\ WILLIAM STRICKLAND
}

(From the Departments of Internal Medicine, Obstetrics and Gynecology, and Surgery, University of Texas Southwestern Medical School, Dallas, Texas)

(Submitted for publication September 21, 1959; accepted November 19, 1959)

There is at present general agreement, based upon abundant in vitro and in vivo experimental evidence, that insulin exerts an immediate and profound effect on glucose utilization by muscle and adipose tissue (1-5). On the other hand, a direct hepatic action of insulin is disclaimed by most investigators since innumerable studies both in vitro and in vivo have failed to demonstrate clearly a consistent and reproducible effect of insulin upon hepatic glucose metabolism (5-12).

Recent observations from this laboratory suggested that the site (13) and the rate (14) of insulin administration are important factors in eliciting a hepatic effect. However, in these as in all previous in vivo studies $(11,15-19)$, the conclusions regarding the hepatic action of insulin were inferential, since the net balance of glucose across the liver was not ascertained by direct measurement.

Any experiments designed to elucidate the effect of insulin on hepatic carbohydrate metabolism should fulfill the following prerequisites:

1. Hepatic, in contrast to splanchnic, glucose metabolism should be measured. In view of the marked sensitivity of the extrahepatic splanchnic tissues to insulin $(1-5,11,12)$, separation of the effects of insulin on these tissues from its effects on the liver is mandatory. This, in turn, re-

* This work was supported in part by a grant from the Upjohn Company and in part by the Dallas Heart Association.

† Presented in part before the Metabolism Section of the American Society for Clinical Investigation, Atlantic City, May 3, 1959, and at the Symposium on Insulin and Oral Hypoglycemic Agents held at the Indiana University Medical Center, Indianapolis, February 27 and 28, 1959.

$\$$ Established Investigator of The American Heart Association. quires the measurement not only of arterial, portal venous and hepatic venous glucose concentration but also measurement of the precise contributions of portal venous and hepatic arterial inflow to total hepatic blood flow. This is not possible in the intact animal because of the wide and capricious variation in the contribution of portal venous inflow to total hepatic blood flow, which may change from as little as 10 per cent to as much as 90 per cent of total hepatic blood flow (20).

2. Insulin should be administered in a manner which minimizes the counter-regulatory response to hypoglycemia. Profound hypoglycemia with its attendant release of epinephrine $(21,22)$, adrenal cortical hormones $(23,24)$, and glucagon $(25,26)$, may obscure a hepatic effect of insulin by the marked increase in hepatic glucose release which characterizes the action of these counterregulatory hormones $(27-30)$.

The present experiments were designed to meet these prerequisites in the following manner. First, dogs with complete end-to-side portacaval shunts were studied. This operation completely separates the liver from the remainder of the splanchnic tissues and thereby permits the measurement of hepatic rather than splanchnic glucose metabolism. Second, measures were taken to minimize or prevent the counter-regulatory mechanisms to hypoglycemia. In one group of experiments, insulin was administered by slow infusion which produced a very gradual modest decline in arterial glucose concentration. In another group, the hypoglycemic stimulus was further reduced in magnitude and duration by administering glucose after insulin infusion had been started. Finally hypoglycemia was prevented by using diabetic dogs with fasting hyperglycemia. 


\section{METHODS AND PROCEDURE}

Complete end-to-side portacaval anastomoses were performed in one stage on adult mongrel dogs under general ether anesthesia. A minimal period of two weeks after portacaval surgery was allowed to pass prior to the performance of the experimental studies. By this time, the dogs had completely recovered from the operative procedure. Food was removed from the cages 15 hours before the dogs were anesthetized with Nembutal ( $25 \mathrm{mg}$ per $\mathrm{kg}$ intravenously), which has been shown to alter neither hepatic blood flow nor hepatic oxygen utilization $(31,32)$. Hepatic venous blood samples were collected through a cardiac catheter inserted into an external jugular vein and guided deep into a hepatic vein under fluoroscopic control. Position of the hepatic venous catheter was checked frequently during each experiment. Arterial samples were obtained through an indwelling Cournand needle placed in a femoral artery.

Hepatic blood flow (EHBF) was estimated at $10 \mathrm{~min}$ ute intervals by the clearance and extraction method of Bradley, Ingelfinger, Bradley and Curry (33), using $I^{131}$ labeled rose bengal as the extractable material. The validity of the clearance and extraction method of estimating hepatic blood flow in the presence of a portacaval shunt has been established by Bradley and co-workers (34). I ${ }^{131}$-rose bengal has been shown to be a satisfactory substance for the measurement of hepatic blood flow (35). A solution of isotonic saline containing $20 \mu \mathrm{c}$ of $\mathrm{I}^{131}$-labeled rose bengal per $100 \mathrm{ml}$ was administered intravenously at a constant rate of approximately $1 \mathrm{ml}$ per minute by means of a Bowman pump. After one hour to allow for equilibration, $3 \mathrm{ml}$ samples of blood were drawn simultaneously from the femoral artery and hepatic vein at 10 minute intervals. Each sample was hemolyzed with powdered saponin and the radioactivity contained in duplicate $1 \mathrm{ml}$ aliquots of the hemolyzed blood was measured in a deep-well scintillation counter. The coefficient of variation of the mean of pair detcrminations of $I^{131}$-rose bengal from a group average is 0.52 per cent (36). Hepatic extraction of $I^{131}$-rose bengal always exceeded the minimum criteria of Bradley and associatcs (34), most values being in the range of 15 to 30 per cent.

Hepatic blood flow was calculated from extrapolated data midway between two successive determinations of arterial and hepatic venous blood radioactivity by means of the formula:

$$
\mathrm{EHBF}=\frac{\mathrm{I} \pm \Delta \mathrm{A}_{\mathrm{c}} \times \mathrm{BV}}{\mathrm{A}_{\mathrm{c}}-\mathrm{HV}_{\mathrm{C}}},
$$

where $\mathrm{EHBF}$ = estimated hepatic blood flow in milliliters per minute; $I$ = infusion rate of $I^{131}$-labeled rose bengal in counts per minute per minute; $\Delta \mathbf{A}_{\mathbf{c}}=$ change in counts per milliliter of arterial blood per minute; $\mathrm{BV}=$ total blood volume in milliliters, estimated as 9 per cent of body weight; $A_{\mathbf{C}}=$ counts per minute per milliliter of arterial blood; and $\mathrm{HV}_{\mathbf{C}}=$ counts per minute per milliliter of hepatic vein blood.
Midway between the sampling times for radioactivity, $4 \mathrm{ml}$ of blood was drawn simultaneously, with adequate precaution to prevent catheter dead space error, and at a constant rate over a 100 second interval from the femoral artery and hepatic vein for determination of glucose. To minimize glycolysis the blood was placed immediately into iced tubes containing oxalate and sodium fluoride and protein-free filtrates were prepared within 10 minutes of collection. Blood glucose was determined in triplicate on each sample by the Somogyi copper iodometric method on $5 \mathrm{ml}$ of blood filtrate prepared immediately from $3 \mathrm{ml}$ blood samples, thereby providing a valid measurement of blood glucose within $1 \mathrm{mg}$ per 100 $\mathrm{ml}(37,38)$. Hepatic glucose output (HGO) in milligrams per minute at each 10 minute interval was calculated as the product of the estimated hepatic blood flow $(\mathrm{EHBF})$ and the hepatic venous-femoral arterial glucose concentration difference ( $\mathrm{HV}-\mathrm{A})$.

One group of experiments was designed to contrast the effects of the slow intravenous infusion and rapid intravenous injection of insulin on hepatic glucose metabolism. After three or four control determinations of hepatic glucose output, glucagon-free insulin ${ }^{1}$ was administered into a hind leg vein either slowly by constant infusion at a rate of 0.025 to 0.08 unit per minute in eight studies, ${ }^{2}$ or rapidly in amounts of 5 to 9 units over a period of 15 seconds in six studies. Hepatic glucose output was then measured at 10 minute intervals over the ensuing 60 to 90 minutes. In some studies, the constant infusion of insulin was stopped, and additional determinations were obtained during the "recovery" period.

Ten additional studies were performed under circumstances calculated either to prevent or to reduce the magnitude of the hypoglycemic stimulus. In six experiments, insulin was administered at a rate of 0.026 to 0.065 unit per minute by constant infusion in the usual manner. Thirty to 40 minutes after the start of the insulin infusion, glucose was added to the infusion and delivered at a rate of 25 to $200 \mathrm{mg}$ per minute. Four other studies were performed in diabetic dogs with portacaval shunts. Diabetes was produced by the combination of subtotal pancreatectomy and alloxanization at least three weeks before each experiment. In these studies arterial glucose concentration fell from hyperglycemic levels during insulin infusion but never reached hypoglycemic levels.

\section{RESULTS}

\section{Effect on hepatic glucose output}

A. Slow infusion of insulin. Insulin administered by slow intravenous infusion resulted, in each of the eight dogs, in an immediate and sig-

${ }^{1} \mathrm{We}$ are indebted to Dr. W. R. Kirtley of the Eli Lilly Company for the generous supply of glucagon-free insulin.

2 See Tables I, III, IV and V for the precise dose of insulin in units per kilogram per hour. 


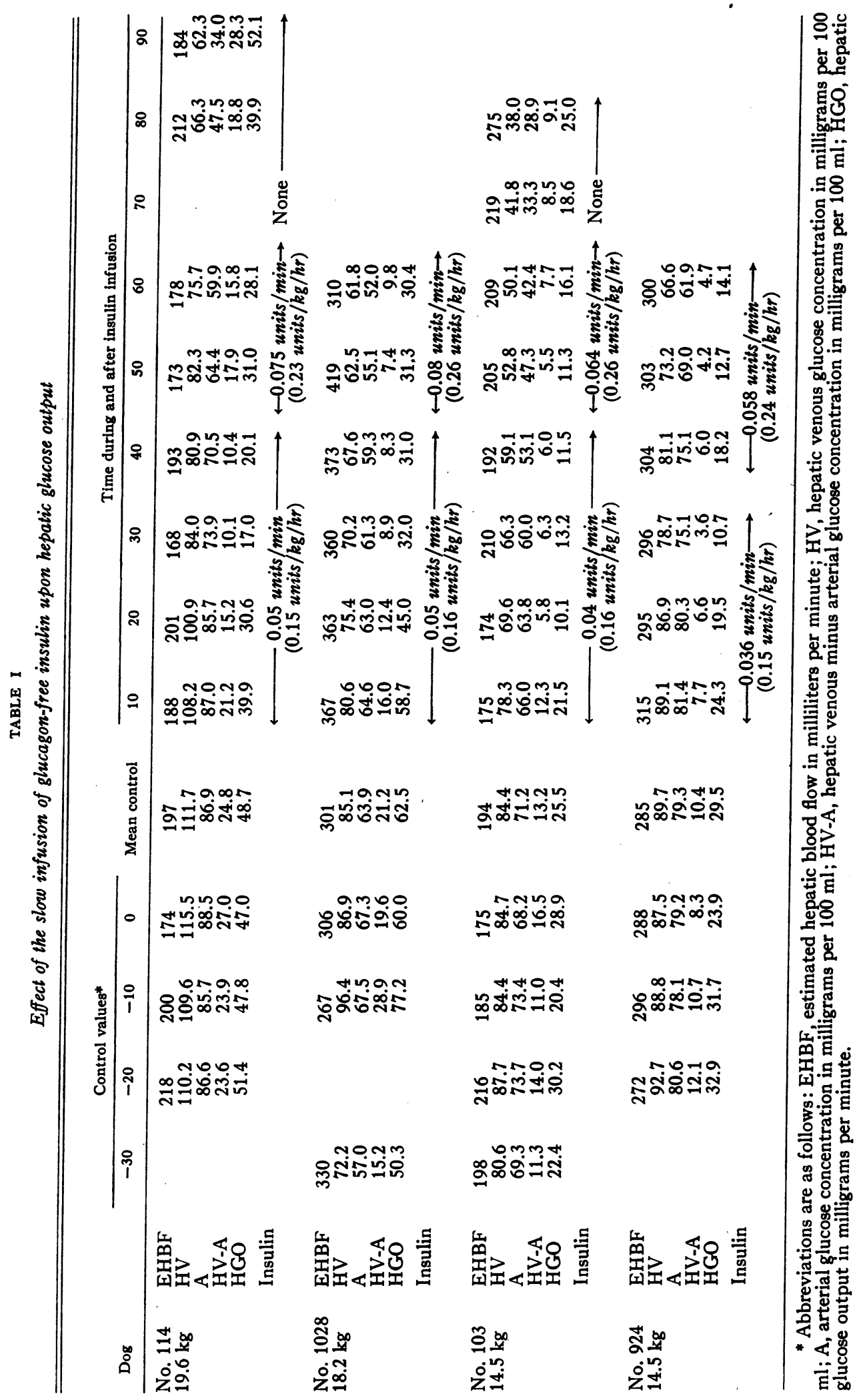




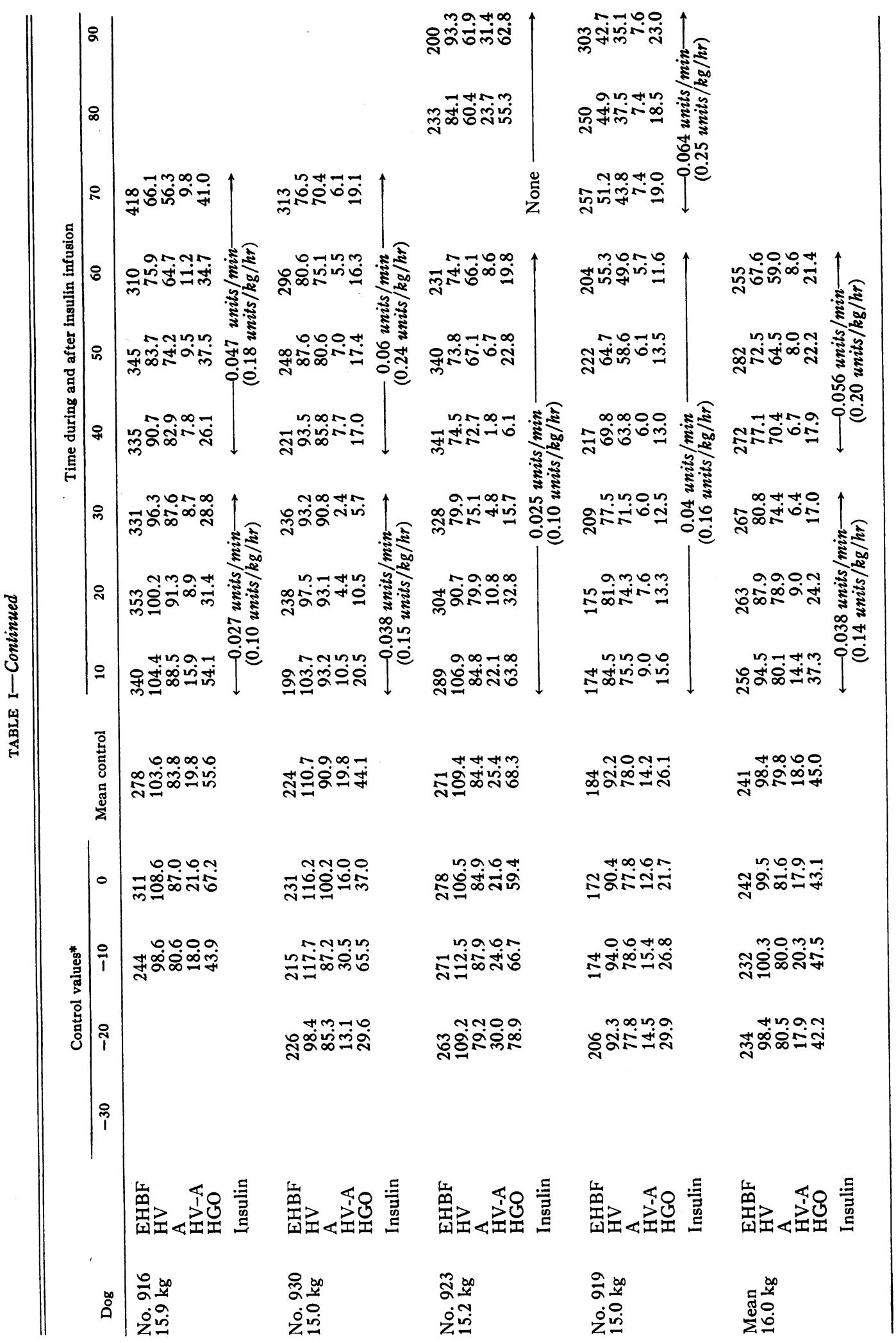




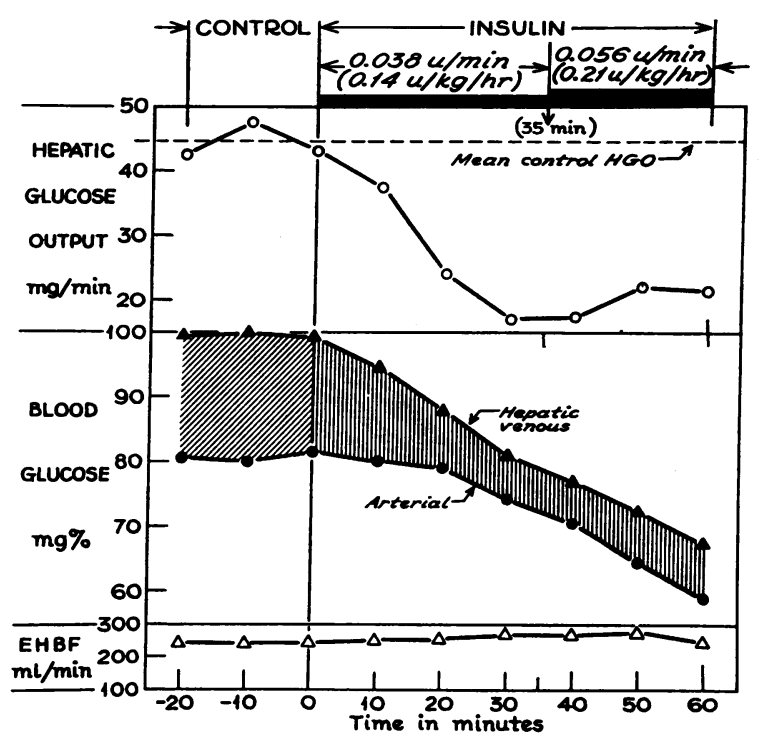

Fig. 1. Mean changes in hepatic venous and aRTERIAL GLUCOSE CONCENTRATIONS, HEPATIC BLOOD FLOW, AND THE HEPATIC GLUCOSE OUTPUT DURING THE SLOW INFUSION OF GLUCAGON-FREE INSULIN.

nificant (36) decline in hepatic glucose output (Tables I and II). The 44 per cent fall in mean hepatic glucose output, from the control value of $45 \mathrm{mg}$ per minute to the mean value of $25.3 \mathrm{mg}$ per minute during the 60 minute period of insulin infusion, was attributed to a 52 per cent decrease in mean HV-A glucose difference which fell from $18.6 \mathrm{mg}$ per $100 \mathrm{ml}$ to $8.8 \mathrm{mg}$ per $100 \mathrm{ml}$ (Figure 1). During the last 30 minutes of insulin infusion, hepatic glucose output and HV-A glucose difference averaged $19.8 \mathrm{mg}$ per minute and 7.4

TABLE II

Changes in hepatic glucose output from control during the slow infusion of insulin

\begin{tabular}{cccccccc}
\hline \hline & \multicolumn{6}{c}{ Hepatic glucose output, $\mathrm{mg} / \mathrm{min}$} \\
\cline { 2 - 8 } Dog & $\begin{array}{c}\text { Mean } \\
\text { nocrease from control } \\
\text { control }\end{array}$ & \multicolumn{6}{c}{ Minutes after start of insulin infusion } \\
\cline { 2 - 8 } & 10 & 20 & 30 & 40 & 50 & 60 \\
\hline 114 & 47.8 & 7.9 & 10.1 & 30.8 & 27.7 & 16.8 & 19.7 \\
1028 & 62.5 & 3.8 & 17.5 & 30.5 & 31.5 & 31.2 & 32.1 \\
103 & 25.5 & 4.0 & 15.4 & 12.3 & 14.0 & 14.2 & 9.4 \\
924 & 29.5 & 5.2 & 10.0 & 18.8 & 11.3 & 16.8 & 15.4 \\
916 & 55.6 & 1.5 & 24.2 & 26.8 & 29.5 & 18.1 & 20.9 \\
930 & 44.1 & 23.6 & 33.6 & 38.4 & 27.1 & 26.7 & 27.8 \\
923 & 68.3 & 4.5 & 35.5 & 48.1 & 62.2 & 45.5 & 48.5 \\
919 & 26.1 & 10.5 & 12.8 & 13.6 & 13.1 & 12.6 & 14.5 \\
Mean & & 7.6 & 19.9 & 27.4 & 27.0 & 22.7 & 23.5 \\
p & & $<0.02$ & $<0.01$ & $<0.01$ & $<0.01$ & $<0.01$ & $<0.01$ \\
& & & & & & &
\end{tabular}

mg per $100 \mathrm{ml}$, a fall of 56 and 60 per cent, respectively, from control values (Figures 1 and 2).

B. Rapid intravenous injection of insulin. In contrast to the immediate and striking decrease in hepatic glucose output associated with the slow infusion of insulin, the rapid intravenous injection of insulin did not decrease hepatic glucose output (Table III). In no instance did hepatic glucose output fall significantly during the first 40 minutes after rapid insulin injection when mean arterial blood glucose concentration was continuously falling. During this time hepatic glucose output averaged $51.0 \mathrm{mg}$ per minute, a 21 per cent increase over the control value. From

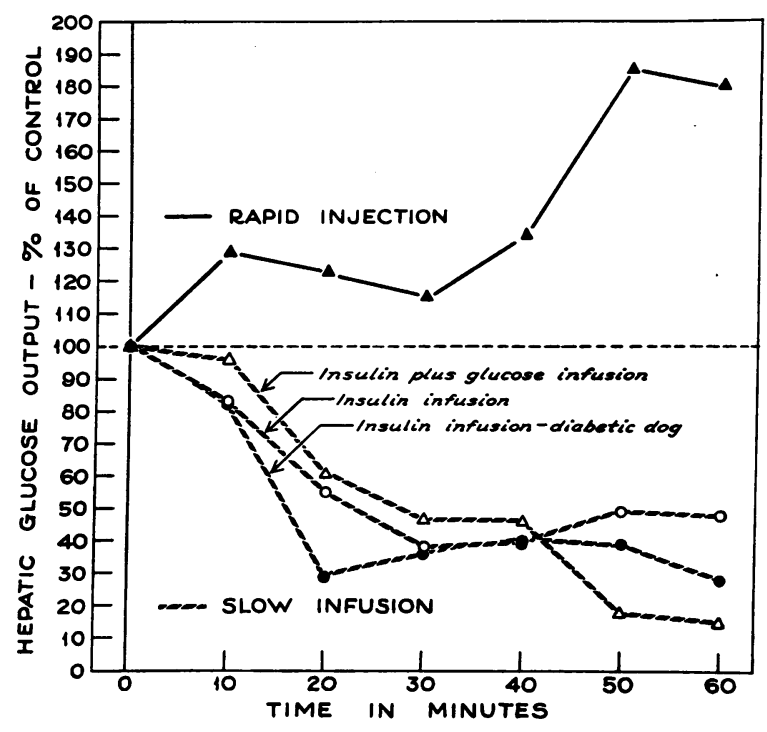

Fig. 2. Comparison of the mean changes in hePATIC GLUCOSE OUTPUT FOLLOWING RAPID INTRAVENOUS INJECTION AND DURING THE SLOW INTRAVENOUS INFUSION OF GLUCAGON-FREE INSULIN.

40 to 70 minutes, when arterial blood glucose stopped falling and rose slightly, mean hepatic glucose output was $72.3 \mathrm{mg}$ per minute, a value 74 per cent above control (Figures 2 and 3 ).

C. Studies in which hypoglycemia was minimized or prevented. In the diabetic dogs with portacaval shunts, mean hepatic glucose output decreased 51 per cent from the control value of $76.8 \mathrm{mg}$ per minute to a mean value of $37.9 \mathrm{mg}$ per minute during the 60 minute period of insulin infusion (Table IV). During this time, HV-A glucose difference fell 65 per cent from 24.8 to $8.7 \mathrm{mg}$ per $100 \mathrm{ml}$. From 30 to 60 minutes after 
MADISON, COMBES, ADAMS AND STRICKLAND

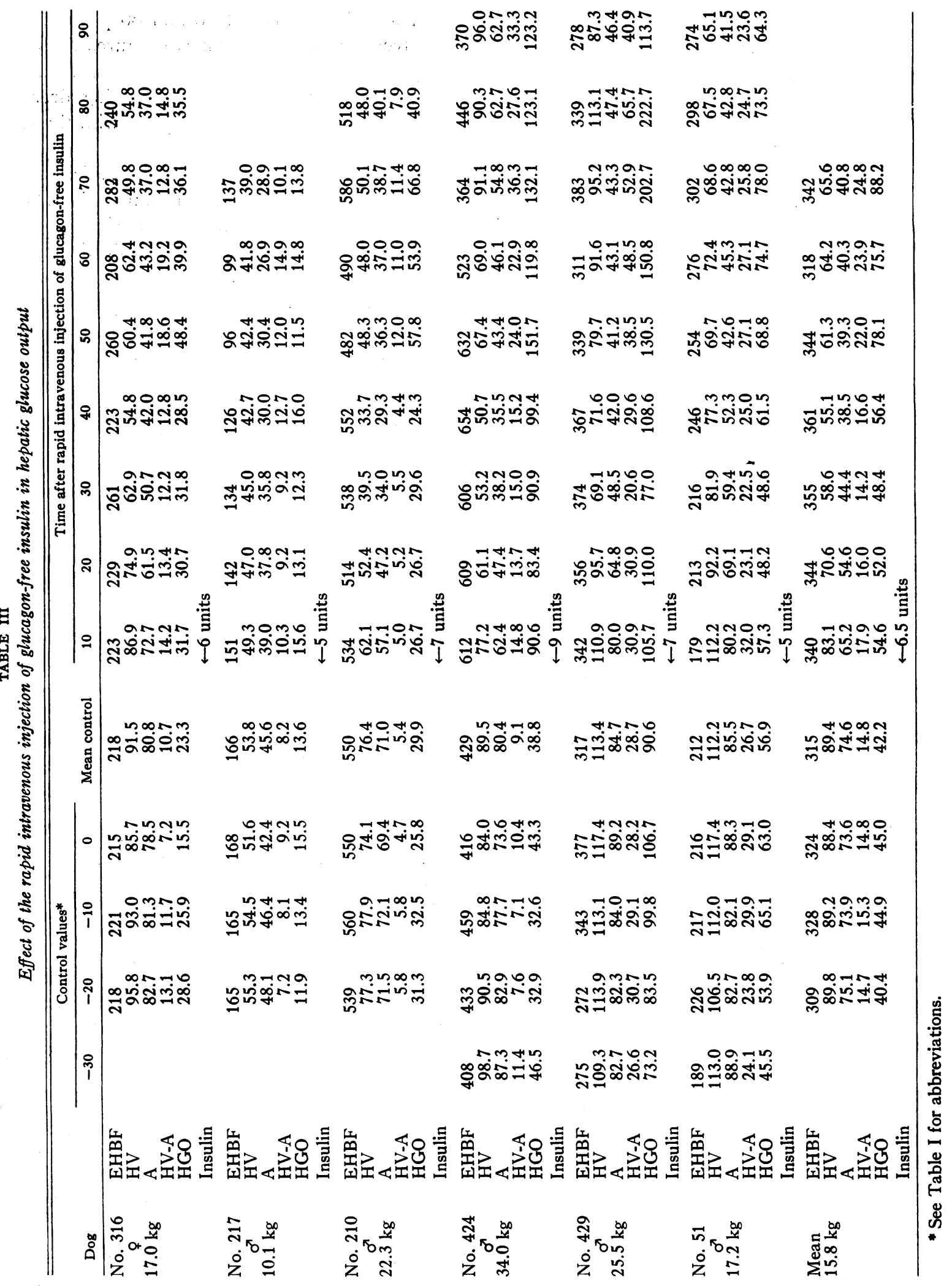


starting the insulin infusion, hepatic glucose output and HV-A glucose difference averaged 28.5 $\mathrm{mg}$ per minute and $6.7 \mathrm{mg}$ per $100 \mathrm{ml}$, a fall of 63 and 73 per cent, respectively, from control values (Figures 2 and 4 ).

The administration of glucose following the start of the insulin infusion resulted in the greatest drop in hepatic glucose output although mean arterial glucose concentration remained below control values (Table V, Figures 2 and 5). After 30 minutes of insulin infusion, before glucose was administered, mean hepatic glucose

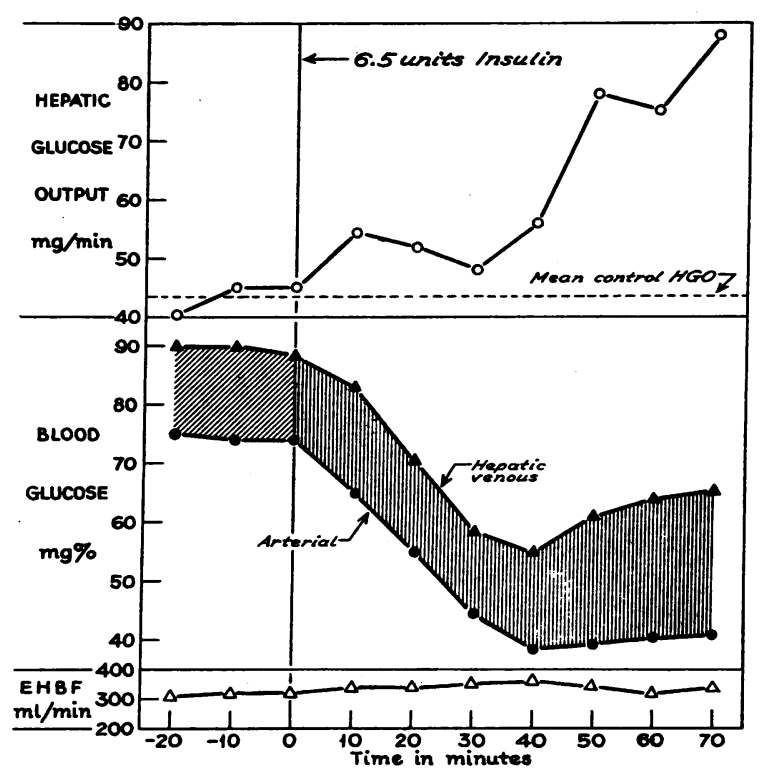

Fig. 3. Mean changes in hepatic venous and arTERIAL GLUCOSE CONCENTRATIONS, HEPATIC BLOOD FLOW, AND THE HEPATIC GLUCOSE OUTPUT AFTER THE RAPID INTRAVENOUS INJECTION OF GLUCAGON-FREE INSULIN.

output had fallen to $20.4 \mathrm{mg}$ per minute, a 53 per cent decline from the control value of 43.3 $\mathrm{mg}$ per minute (Table V). During the last 30 minutes when glucose was infused with insulin, hepatic glucose output declined strikingly and averaged only $7.3 \mathrm{mg}$ per minute, an 83 per cent reduction from the mean control. This marked depression in mean hepatic glucose output occurred despite a rise of only $5.3 \mathrm{mg}$ per $100 \mathrm{ml}$ in mean arterial glucose concentration, which remained 10.3 per cent below the mean control value (Figure 5). Not only was mean hepatic glucose output reduced to lower levels than in any of the

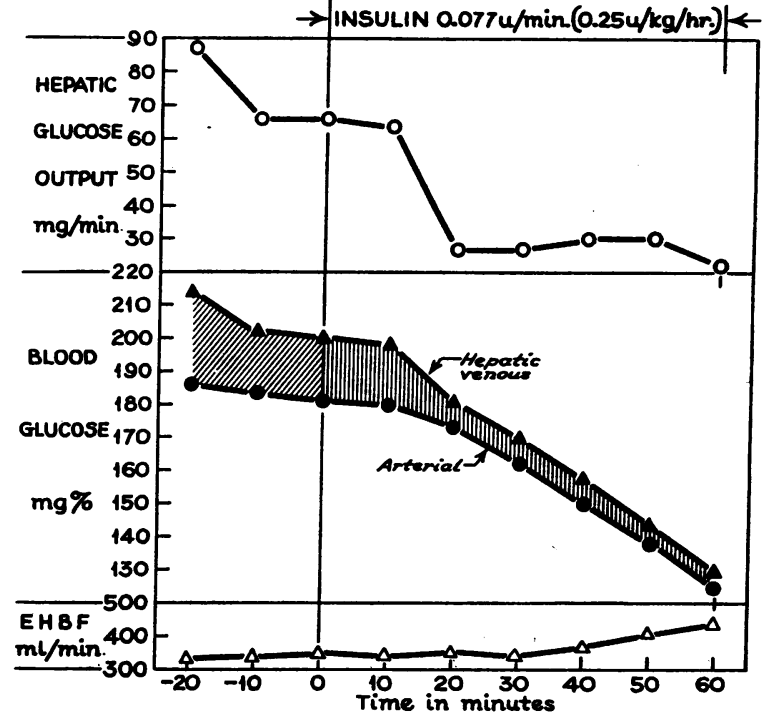

Fig. 4. Mean changes in hepatic venous and aRTERIAL GLUCOSE CONCENTRATIONS, HEPATIC BLOOD FLOW, AND THE HEPATIC GLUCOSE OUTPUT IN DIABETIC DOGS DURING THE SLOW INTRAVENOUS INFUSION OF GLUCAGONFREE INSULIN.

other experiments (Figure 2), but in Dog 119 (Table V) actual storage of glucose by the liver occurred when arterial blood glucose concentration was about $10 \mathrm{mg}$ per $100 \mathrm{ml}$ below the control level.

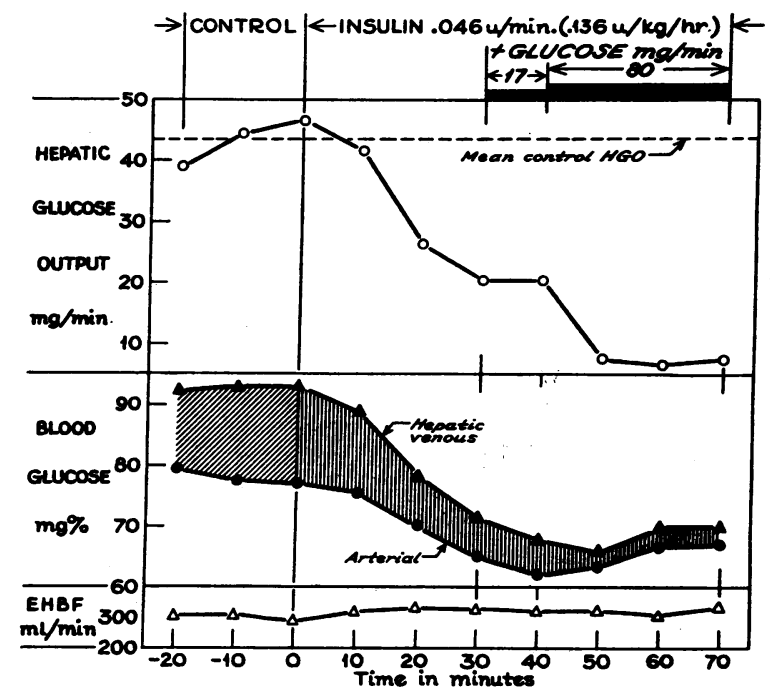

Fig. 5. Mean changes in hepatic venous and aRTERIAL GLUCOSE CONCENTRATIONS, HEPATIC BLOOD FLOW, AND THE HEPATIC GLUCOSE OUTPUT DURING THE SLOW INFUSION OF GLUCAGON-FREE INSULIN PLUS GLUCOSE. 
TABLE IV

Effect of infusion of glucagon-free insulin on the hepatic glucose output of diabetic dogs

\begin{tabular}{|c|c|c|c|c|c|c|c|c|c|c|c|c|}
\hline \multirow[b]{2}{*}{ Dog } & & \multicolumn{4}{|c|}{ Control values*. } & \multirow[b]{2}{*}{ Mean control } & \multicolumn{6}{|c|}{ Time during insulin infusion } \\
\hline & & -30 & -20 & -10 & $\mathbf{0}$ & & 10 & 20 & 30 & 40 & 50 & 60 \\
\hline \multirow[t]{2}{*}{$\begin{array}{l}\text { No. } 42 \\
\text { ơ }^{7} \\
23.7 \mathrm{~kg}\end{array}$} & $\begin{array}{l}\text { EHBF } \\
\text { HV } \\
\text { A } \\
\text { HV-A } \\
\text { HGO }\end{array}$ & & $\begin{array}{r}572 \\
145.5 \\
134.5 \\
11.0 \\
62.9\end{array}$ & $\begin{array}{l}533 \\
150.2 \\
128.7 \\
21.5 \\
114.5\end{array}$ & $\begin{array}{r}612 \\
152.0 \\
136.3 \\
15.7 \\
96.1\end{array}$ & $\begin{array}{l}572 \\
149.2 \\
133.1 \\
16.1 \\
91.2\end{array}$ & $\begin{array}{r}571 \\
154.9 \\
140.2 \\
14.7 \\
83.9\end{array}$ & $\begin{array}{r}527 \\
146.5 \\
138.7 \\
7.8 \\
41.1\end{array}$ & $\begin{array}{r}526 \\
141.5 \\
130.3 \\
11.2 \\
58.9\end{array}$ & $\begin{array}{r}527 \\
129.0 \\
119.8 \\
9.2 \\
48.5\end{array}$ & $\begin{array}{r}505 \\
114.3 \\
105.4 \\
8.9 \\
44.9\end{array}$ & $\begin{array}{r}597 \\
100.9 \\
94.1 \\
8.8 \\
40.6\end{array}$ \\
\hline & Insulin & & & & & & & \multicolumn{4}{|c|}{0.079 units $/ \mathrm{min}(0.2$ units $/ \mathrm{kg} / \mathrm{hr})$} & $\longrightarrow$ \\
\hline \multirow[t]{2}{*}{$\begin{array}{l}\text { No. } 417 \\
\sigma^{7} \\
17.2 \mathrm{~kg}\end{array}$} & $\begin{array}{l}\text { EHBF } \\
\text { HV } \\
\text { A } \\
\text { HV-A } \\
\text { HGO }\end{array}$ & & $\begin{array}{r}181 \\
215.0 \\
188.9 \\
26.1 \\
47.2\end{array}$ & $\begin{array}{r}175 \\
199.2 \\
183.6 \\
15.6 \\
27.4\end{array}$ & $\begin{array}{r}164 \\
193.6 \\
176.1 \\
17.5 \\
28.9\end{array}$ & $\begin{array}{l}173 \\
202.6 \\
182.9 \\
19.7 \\
34.5\end{array}$ & $\begin{array}{r}185 \\
177.3 \\
168.3 \\
9.0 \\
16.7\end{array}$ & $\begin{array}{r}183 \\
166.5 \\
160.5 \\
6.0 \\
11.0\end{array}$ & $\begin{array}{r}169 \\
158.4 \\
151.2 \\
7.2 \\
12.2\end{array}$ & $\begin{array}{r}178 \\
150.4 \\
146.6 \\
3.8 \\
6.8\end{array}$ & $\begin{array}{r}189 \\
143.1 \\
138.3 \\
4.8 \\
9.1\end{array}$ & $\begin{array}{r}193 \\
132.0 \\
128.5 \\
3.5 \\
6.8\end{array}$ \\
\hline & Insulin & & & & & & $\longleftarrow$ & \multicolumn{4}{|c|}{0.086 units $/ \min (0.3$ units $/ \mathrm{kg} / \mathrm{hr})$} & \\
\hline \multirow[t]{2}{*}{$\begin{array}{l}\text { No. } 529 \\
17.7^{+} \mathrm{kg}\end{array}$} & $\begin{array}{l}\text { EHBF } \\
\text { HV } \\
\text { A } \\
\text { HV-A } \\
\text { HGO }\end{array}$ & $\begin{array}{r}235 \\
297.3 \\
235.0 \\
62.3 \\
146.4\end{array}$ & $\begin{array}{r}308 \\
299.3 \\
237.5 \\
61.8 \\
190.3\end{array}$ & $\begin{array}{r}333 \\
262.8 \\
242.5 \\
20.3 \\
67.6\end{array}$ & $\begin{array}{l}380 \\
259.0 \\
238.3 \\
20.7 \\
78.7\end{array}$ & $\begin{array}{r}314 \\
279.6 \\
238.3 \\
41.3 \\
120.8\end{array}$ & $\begin{array}{r}342 \\
269.8 \\
239.8 \\
30.0 \\
102.6\end{array}$ & $\begin{array}{c}448 \\
238.0 \\
233.8 \\
4.2 \\
18.8\end{array}$ & $\begin{array}{r}384 \\
225.0 \\
220.0 \\
5.0 \\
19.2\end{array}$ & $\begin{array}{r}411 \\
220.3 \\
209.0 \\
11.3 \\
46.4\end{array}$ & $\begin{array}{r}498 \\
207.0 \\
198.5 \\
8.5 \\
42.3\end{array}$ & $\begin{array}{r}466 \\
192.0 \\
187.5 \\
4.5 \\
21.0\end{array}$ \\
\hline & Insulin & & & & & & \multicolumn{5}{|c|}{$\longleftarrow 0.074$ units $/ \min (0.25$ units $/ \mathrm{kg} / \mathrm{hr})$} & \\
\hline \multirow[t]{2}{*}{$\begin{array}{c}\text { No. } 729 \\
\sigma^{7} \\
16.8 \mathrm{~kg}\end{array}$} & $\begin{array}{l}\text { EHBF } \\
\text { HV } \\
\text { A } \\
\text { HV-A } \\
\text { HGO }\end{array}$ & $\begin{array}{r}267 \\
212.7 \\
181.0 \\
31.7 \\
84.6\end{array}$ & $\begin{array}{r}283 \\
198.2 \\
181.8 \\
16.4 \\
46.4\end{array}$ & $\begin{array}{r}317 \\
196.2 \\
179.5 \\
16.7 \\
52.9\end{array}$ & $\begin{array}{r}246 \\
198.4 \\
174.6 \\
23.8 \\
58.5\end{array}$ & $\begin{array}{r}277 \\
201.4 \\
179.2 \\
22.2 \\
60.6\end{array}$ & $\begin{array}{r}282 \\
190.4 \\
171.9 \\
18.5 \\
52.2\end{array}$ & $\begin{array}{r}264 \\
174.4 \\
161.2 \\
13.2 \\
34.8\end{array}$ & $\begin{array}{r}289 \\
155.1 \\
149.3 \\
5.8 \\
16.8\end{array}$ & $\begin{array}{r}402 \\
131.6 \\
126.8 \\
4.8 \\
19.3\end{array}$ & $\begin{array}{r}473 \\
114.1 \\
108.2 \\
5.9 \\
27.9\end{array}$ & $\begin{array}{r}531 \\
95.1 \\
91.8 \\
3.3 \\
17.5\end{array}$ \\
\hline & Insulin & & & & & & \multicolumn{5}{|c|}{$\longleftarrow 0.070$ units $/ \min (0.25$ units $/ \mathrm{kg} / \mathrm{hr})$} & \\
\hline \multirow[t]{2}{*}{$\begin{array}{l}\text { Mean } \\
18.9 \mathrm{~kg}\end{array}$} & $\begin{array}{l}\text { EHBF } \\
\text { HV } \\
\text { A } \\
\text { HV-A } \\
\text { HGO }\end{array}$ & & $\begin{array}{r}336 \\
214.5 \\
185.7 \\
28.8 \\
86.7\end{array}$ & $\begin{array}{l}339 \\
202.1 \\
183.5 \\
18.5 \\
65.6\end{array}$ & $\begin{array}{l}350 \\
200.7 \\
181.3 \\
19.4 \\
65.6\end{array}$ & $\begin{array}{r}334 \\
208.2 \\
183.4 \\
24.8 \\
76.8\end{array}$ & $\begin{array}{l}345 \\
198.1 \\
180.0 \\
18.1 \\
63.9\end{array}$ & $\begin{array}{r}356 \\
181.4 \\
173.6 \\
7.8 \\
26.4\end{array}$ & $\begin{array}{r}342 \\
170.0 \\
162.7 \\
7.3 \\
26.8\end{array}$ & $\begin{array}{r}379 \\
157.8 \\
150.5 \\
7.3 \\
30.2\end{array}$ & $\begin{array}{r}416 \\
144.6 \\
137.6 \\
7.0 \\
31.0\end{array}$ & $\begin{array}{r}447 \\
130.0 \\
125.5 \\
4.5 \\
21.5\end{array}$ \\
\hline & Insulin & & & & & & \multicolumn{6}{|c|}{$\longleftarrow 0.077$ units $/$ min $(0.25$ units $/ \mathrm{kg} / \mathrm{hr}) \longrightarrow$} \\
\hline
\end{tabular}

* See Table I for abbreviations.

\section{Calculated effect of insulin on peripheral glu-} cose utilization

These data on the changes in hepatic glucose output give some insight into the approximate alterations in peripheral glucose utilization which attend the slow infusion and rapid injection of insulin. Assuming a glucose space ${ }^{3}$ of 30 per cent of the body weight of the dog (39-41), the magnitude of the glucose pool prior to and after in-

3 The glucose space has been variously estimated between 19.5 and 30 per cent of body weight $(39,40)$. In dogs it is apparently close to 25 per cent (41). The larger estimate, 30 per cent of body weight, was used in these calculations in order to correct for the 12 per cent higher concentration of glucose in plasma compared to whole blood and, therefore, to prevent overestimation of the hepatic contribution to total decrease in glucose pool. sulin administration can be calculated. Since the hepatic contribution to this change in glucose pool is known, alterations in peripheral glucose utilization occurring simultaneously can be approximately estimated. The calculated data indicate three different types of response to insulin, apparently dependent upon the rate of insulin administration and the availability of glucose for peripheral utilization (Table VI). First, when insulin was administered by slow infusion in nondiabetic dogs, the decrease in mean hepatic glucose output accounted for the entire reduction in the size of the glucose pool, there being, therefore, no evidence of increased peripheral glucose utilization. Second, precisely the reverse changes occurred following the rapid injection of insulin. Since hepatic glucose output increased, the entire 


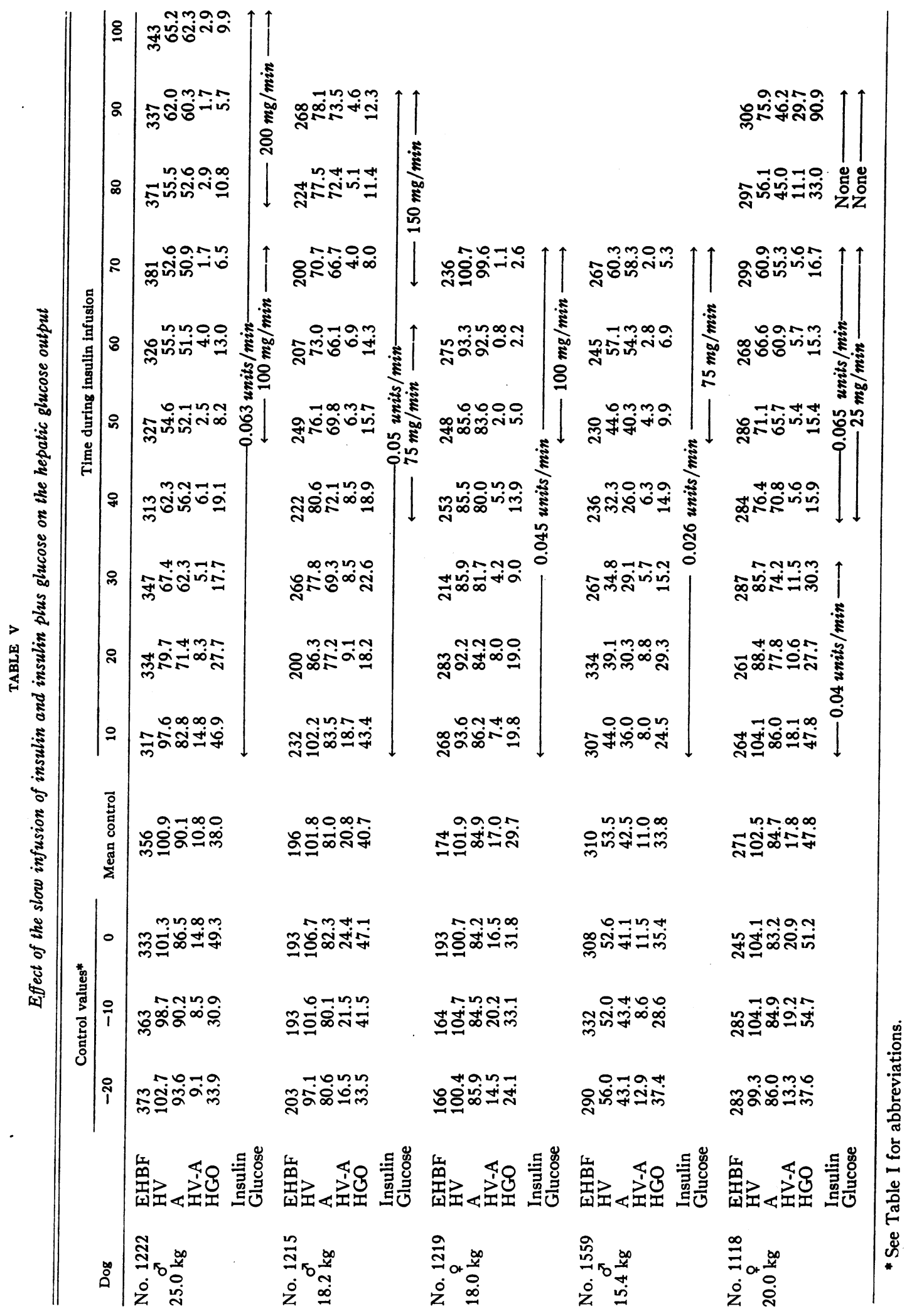



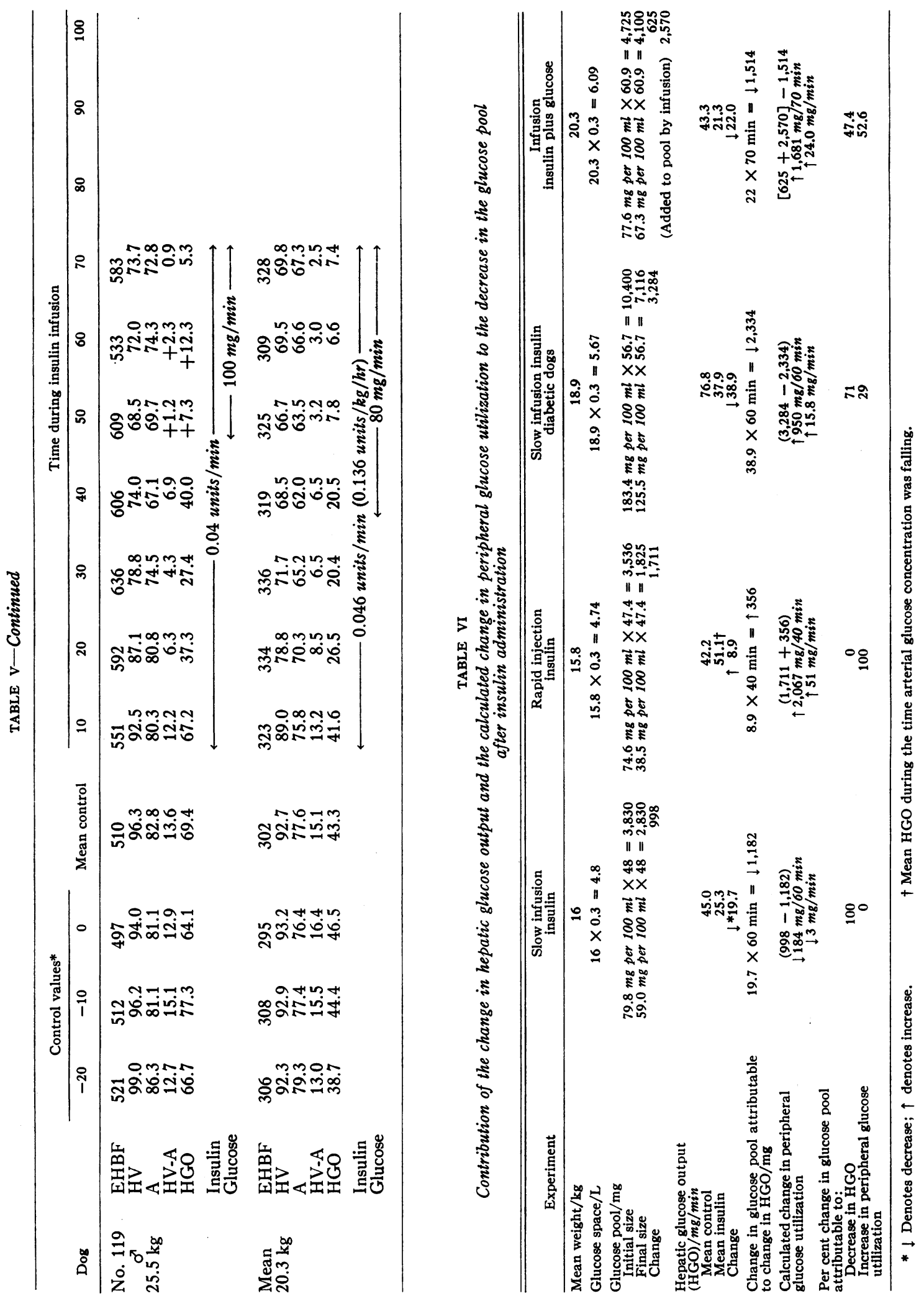
decline in the glucose pool must have been the consequence of a marked increase in peripheral glucose utilization. These data confirm a previous study from this laboratory (14) in which the effects of the slow infusion and rapid injection of insulin on peripheral glucose utilization, as reflected by changes in femoral arteriovenous glucose difference, were compared in normal human subjects. Following the rapid injection of insulin, mean arteriovenous glucose difference increased from 1.8 to $9.3 \mathrm{mg}$ per $100 \mathrm{ml}$, whereas during the fall in arterial glucose concentration which attended the slow infusion of insulin, mean arteriovenous glucose difference narrowed from 1.6 to $0.5 \mathrm{mg}$ per $100 \mathrm{ml}$. Third, when glucose was delivered to the peripheral tissues, as in the diabetic dogs and in those dogs given glucose plus insulin, the decrease in the glucose pool after insulin was the consequence of both a decline in the hepatic output of glucose and of an increase in peripheral glucose utilization (Table VI).

\section{The effect of the establishment of a portacaval} shunt on hepatic blood flow and hepatic glucose metabolism

In the present studies control hepatic blood flow in dogs with portacaval shunts averaged $281 \mathrm{ml}$ per minute or $15 \pm 2.8 \mathrm{ml}$ per $\mathrm{kg}$ per minute. In 17 other studies in dogs without portacaval shunts, which were performed in this laboratory utilizing the same technics, hepatic blood flow averaged $38.3 \mathrm{ml}$ per $\mathrm{kg}$ per minute, a value similar to that reported by others $(42-44)$.

Despite the large decrement in hepatic blood flow, there was no apparent change in hepatic glucose output following the establishment of the portacaval shunt either in these or in other studies (45). Mean control hepatic glucose output of $2.36 \pm 0.9 \mathrm{mg}$ per $\mathrm{kg}$ per minute found in these studies compares closely with values of $2.0 \pm 0.2$ $\mathrm{mg}$ per $\mathrm{kg}$ per minute reported by Lipscomb and Crandall (46) and $2.29 \mathrm{mg}$ per $\mathrm{kg}$ per minute recalculated from the data of Steele and associates (47).

\section{DISCUSSION}

Under conditions of these experiments, an immediate and significant decline in hepatic glucose output occurred in response to insulin whenever it was administered in a manner calculated to reduce counter-regulatory mechanisms to hypoglycemia (Tables I, IV and V). By contrast, when insulin was given by rapid intravenous injection, either no change or an increase in hepatic glucose output was found (Table III). This marked difference in the hepatic action of insulin following the different rates of insulin administration is probably related to the magnitude of stimulation of counter-regulatory mechanisms to hypoglycemia. During the slow infusion of insulin, mean arterial glucose concentration fell only $21 \mathrm{mg}$ per $100 \mathrm{ml}$ in 60 minutes, whereas following the rapid injection of insulin, mean arterial glucose concentration dropped to $38.5 \mathrm{mg}$ per $100 \mathrm{ml}$ in only 40 minutes. The greater release of epinephrine, adrenal cortical hormones and glucagon which would be anticipated when profound hypoglycemia supervenes (21-30) apparently counterbalanced and overwhelmed the effect of insulin on the liver.

The greater decline in hepatic glucose output which occurred when the duration and magnitude of hypoglycemia was further reduced by administering glucose after insulin infusion had been started (Table V), lends strong support to the thesis that by diminishing the homeostatic response to hypoglycemia, a more potent hepatic action of insulin can be unmasked. When insulin alone was infused mean hepatic glucose output fell 56 per cent during the last 30 minutes of infusion, whereas when glucose was added mean hepatic glucose output fell 83 per cent during a similar period of time (Figure 2).

In the experiments in which a direct hepatic effect was demonstrated, insulin was infused into a peripheral vein and reached the liver only after dilution in the blood volume and in the proportion of hepatic blood flow to total cardiac output. This would suggest that even smaller amounts of insulin injected into the portal vein would have a similar, if not greater, hepatic effect. Other published data from this laboratory support the contention that intraportally administered insulin has a greater hepatic action than has insulin given via a peripheral vein (13).

The calculated decline in the glucose pool could be ascribed in large part, if not entirely, to the decrease in hepatic glucose output when insulin alone was administered by slow infusion and to 
the increase in peripheral glucose utilization following the rapid injection of insulin. Just as the hepatic effect of insulin was masked by counterregulatory mechanisms to hypoglycemia, so too was the peripheral effect obscured by the decreased delivery of glucose to the peripheral tissues during insulin infusion (Table VI). In a sense, both circumstances are unphysiological since insulin secretion is usually stimulated by the rising blood glucose concentration that follows a carbohydrate load. Under physiological conditions the magnitude of the hepatic and peripheral contributions to the decrease in the glucose pool more likely approaches that found in the diabetic dogs and in the dogs given insulin plus glucose than that which followed either the slow infusion alone or the rapid injection of insulin (Table VI).

The results of these experiments, which show by direct measurement an immediate effect of insulin upon hepatic glucose output, differ from many other in vivo and in vitro studies which have failed to elicit a consistent and reproducible effect of insulin on the liver (5-12). While a positive in vitro effect of insulin on hepatic glucose metabolism is probably meaningful, the failure to find a consistent effect, or any effect, does not constitute unequivocal evidence that such an action does not exist in the intact organism. The failure to obtain an in vitro effect may be linked with the difficulty in maintaining the integrity of both morphologic and functional organization of the liver and with the inability to simulate precisely in vivo nutritional conditions. Stetten has recently aired the problems inherent in equating rates of metabolic processes or even their presence from in vitro studies on isolated tissues with that which pertains in intact organisms, especially insofar as the liver is concerned (48). The ratelimiting step of a metabolic process in a liver slice may be the rate of transfer of nutrient from the bath to the "liver slice sloshing leisurely in a vessel" (48), a condition quite dissimilar from in vivo studies in which each hepatic cell is in intimate contact with the perfusing blood.

Other in vivo studies have produced inferential data indicating that insulin has a profound and significant effect on hepatic glucose output (16$19,49-53)$, a minor and physiologically insignificant effect (7), and no effect $(6,8-11)$. In view of these different results, a critical analysis of the various technics used is pertinent to help resolve the apparent paradox of these conflicting data. The following differences in experimental design may be related to these discrepant results. 1) In some studies changes in splanchnic rather than in hepatic glucose output were measured $(49-52) ; 2)$ in most studies insulin was administered in amounts and at rates that evoked severe arterial hypoglycemia $(6-11,17,50,51)$ which, in the light of the data from the present study, probably precludes the demonstration of a hepatic effect of insulin ; 3 ) isotopic technics, which measure only hepatic glucose production and are incapable of measuring hepatic glucose utilization, were used $(6-11,17,18)$.

Although Bondy, Bloom, Whitner and Farrar (49), and Bearn, Billing and Sherlock $(50,51)$ reported an immediate effect of insulin on splanchnic glucose metabolism, the limitations of the hepatic venous catheter technic insofar as the measurement of hepatic in contrast to splanchnic glucose metabolism in intact animals is concerned, have been pointed out by Bondy (49) and others $(52,53)$. Shoemaker, Mahler and Ashmore (11) attempted to separate hepatic from extrahepatic splanchnic glucose metabolism by measuring both splanchnic blood flow and the concentrations of glucose in arterial, portal and hepatic venous blood. No decrease in hepatic glucose output following insulin was observed, a finding similar to those experiments in the present study in which marked arterial hypoglycemia was produced; in all but two of their experiments, insulin was administered at rates and in amounts which evoked severe arterial hypoglycemia. Their failure to find a decrease in hepatic glucose output in the two other experiments in which a gradual decline in blood glucose concentration was produced by slow insulin infusion, may be related to their inability to completely separate the hepatic and extrahepatic splanchnic beds by assuming that 80 per cent of total hepatic blood flow is continuously derived from the portal venous inflow. Such an assumption may be unwarranted in view of the wide and momentary fluctuation in the portal venous contribution to total hepatic blood flow reported by Soskin, Essex, Herrick and Mann (20). 
Two other types of studies have been designed to measure the effect of insulin upon hepatic glucose metabolism by following changes in the specific activity of blood glucose, labeled by the administration of a tracer dose of uniformly labeled glucose- $\mathrm{C}^{14}$. Dunn and associates (17) and Jacobs and co-workers (18), utilizing the "single injection" technic, reported a significant decline in hepatic glucose output after insulin administration, particularly when severe hypoglycemia was avoided, whereas no significant hepatic effect of insulin was obtained with the "primer-infusion" technic (7-9). Proponents of the "primer-infusion" technic (8-9) have leveled serious criticism against the interpretation of data from studies using the "single injection" method. The "plateauing" effect following insulin administration in the "single injection" technic, is claimed to be the consequence of a diminished hepatic output of unlabeled glucose $(17,18)$. Others have considered it, in whole or in part, to be an artifact $(6,8,9$, $11,12)$ and attributable to recycling of labeled intermediaries, or to the release of glucose with high isotopic abundance not only from the outer tiers of hepatic glycogen labeled during initial equilibration $(8,12)$ but also from the mucosal cells of the gastrointestinal tract (11). Moreover, in the "single injection" technic the exponential decline in specific activity may represent hepatic output of $\mathrm{C}^{12}$-glucose during a steady state but not necessarily during rapid changes in glucose pool size when the rate of change in pool size is greater than the rate of mixing throughout compartments of the pool $(6-9,54)$. To over-

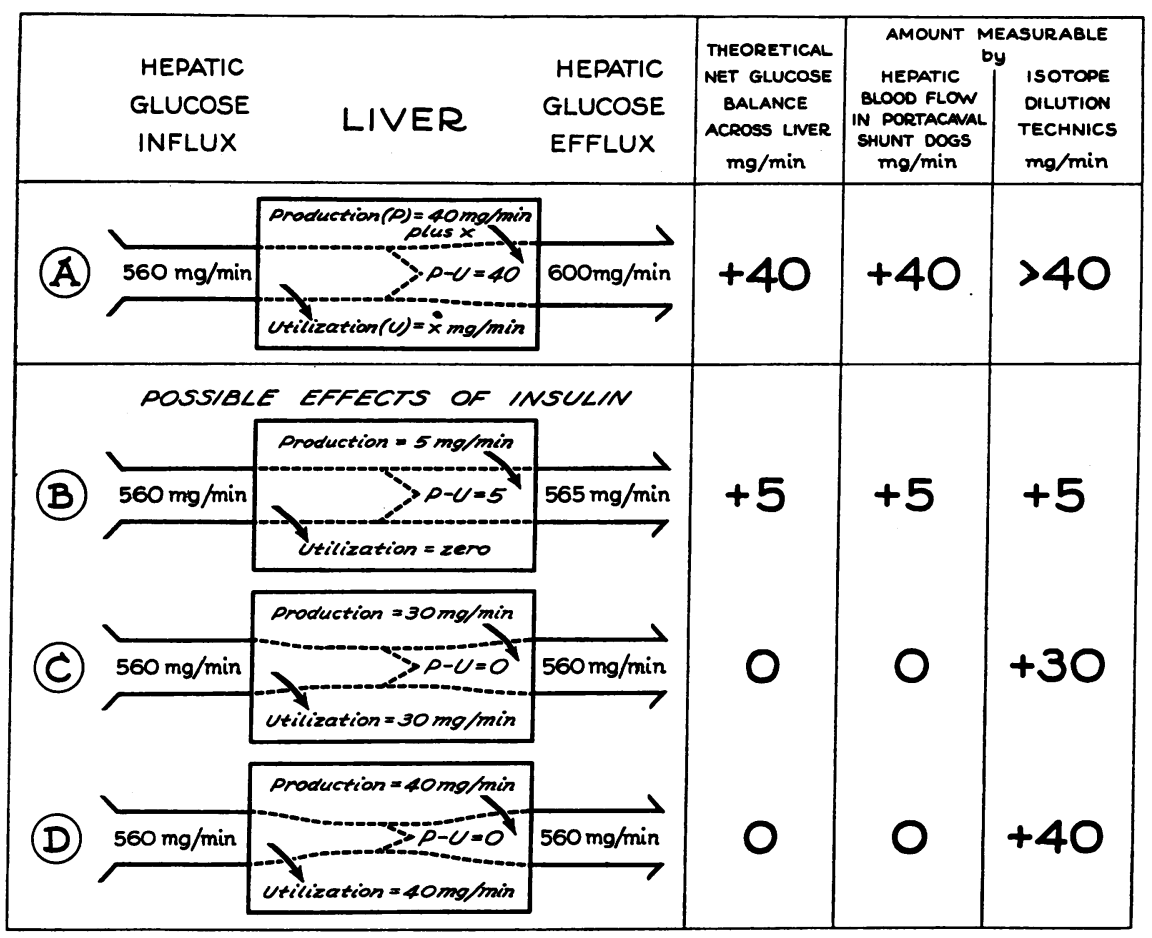

Fig. 6. Comparison of the theoretical Changes in the NET balance of GLUCOSE ACROSS THE LIVER WITH THOSE MEASURED BY THE HEPATIC BLOOD FLOW TECHNIC IN DOGS WITH PORTACAVAL SHUNTS AND BY THE ISOTOPE (GLUCOSE-C ${ }^{14}$ ) DILUtion TECHNICS AFTER INSULIN ADMINistration. The label A refers to the conditions in the postabsorptive state prior to insulin administration. The labels $\mathrm{B}, \mathrm{C}$ and $\mathrm{D}$ identify the theoretically possible effects of insulin on the liver. The magnitude of the theoretical change in net glucose balance across the liver is compared with the magnitude of change each technic is capable of quantitating. Hepatic glucose influx is the total amount of glucose brought to the liver; hepatic efflux the total amount leaving the liver. Efflux equals influx plus hepatic production minus hepatic utilization. See text for details. 
come these objections, Tarding and Schambye combined measurement of total splanchnic glucose output with that of the specific activity of glucose entering and leaving the liver (6), thereby permitting quantitation of hepatic release of unlabeled glucose even at times of rapid change in pool size. Such studies also failed to demonstrate a hepatic action of insulin (6).

In both Tarding's study and in those using the "primer-infusion" technic (7-9), insulin was administered by rapid intravenous injection in most experiments. However, in those instances in which published data are available and in which insulin was given by slow infusion $(6,9)$, no significant decrease in hepatic glucose output was found, a result different from that reported in the present studies.

A serious objection, in the opinion of the present authors, to all the aforementioned isotope dilution studies $(6-11,17-19)$ is that such studies can measure only new glucose production by the liver. Hepatic glucose utilization cannot be measured nor can it be differentiated from peripheral glucose utilization. Only if insulin exclusively or mainly affected new glucose production would these be valid methods for determining the effect of insulin on the liver (Figure 6, Parts A and B). If, on the other hand, initially the major or exclusive hepatic effect of insulin was the stimulation of glucose utilization by the liver cells, the methods would not be sensitive enough to measure a relatively small change in production or would be valueless as a technic for determining the hepatic effect of insulin (Figure 6, Parts C and D). In view of these considerations, the failure to find an effect of insulin on hepatic glucose metabolism by isotopic dilution technics (6-11) does not constitute definitive proof that such an effect does not occur.

The similarity in the hepatic glucose output (2.29 $\mathrm{mg}$ per $\mathrm{kg}$ per minute) found in the isotope dilution studies (47) which measure hepatic glucose production, and in the present studies (2.36 mg per $\mathrm{kg}$ per minute) which measure the net balance of glucose across the liver (production minus utilization), suggests that in the postabsorptive state, prior to insulin administration, hepatic utilization of glucose, like that of muscle (55), is small. Failure of isotope dilution technics (6-9) to detect any decrease in hepatic glu- cose production after insulin administration, whereas an immediate effect was noted in the present studies, implies that initially the major hepatic effect of insulin is the stimulation of glucose utilization by the liver cells, an action quite similar to that which insulin evokes in muscle. In view of the free permeability of liver to glucose (56) in contrast to the permeability of muscle to glucose $(57,58)$, it is possible that in the liver insulin acts either by altering the permeability of some intracellular membrane to glucose, simulating its action on muscle cell membrane, or by changing the activity of hepatic glucokinase. The rapidity with which the change in hepatic glucose output occurred both in normal and diabetic dogs in the present studies may favor its action on an intracellular membrane.

\section{SUMMARY AND CONCLUSIONS}

Twenty-four experiments were performed on dogs with complete end-to-side portacaval shunts to determine whether insulin has a direct effect on hepatic carbohydrate metabolism and also to ascertain whether the rate of insulin administration altered the magnitude of its peripheral and hepatic action. Dogs with portacaval shunts were selected since, in this preparation, the liver is completely separated from the extrahepatic splanchnic bed, thereby permitting measurement of glucose balance across the liver alone rather than across the entire splanchnic bed.

An immediate and physiologically significant effect of insulin on the liver has been demonstrated for the first time by direct measurement; when insulin was administered by slow intravenous infusion in a manner which minimized or prevented hypoglycemia and its attendant counter-regulatory response, a prompt decline in hepatic glucose output of considerable magnitude ensued. In contrast, when insulin was administered by rapid intravenous injection, hepatic glucose output either remained unchanged or increased. The failure of other studies to find a hepatic effect of insulin may be related to the rapid rate of insulin administration and also to the fact that the isotopic dilution technics permit the measurement only of hepatic glucose production and cannot quantitate hepatic glucose utilization. 


\section{REFERENCES}

1. Stadie, W. C. Current concepts of the action of insulin. Physiol. Rev. 1954, 34, 52.

2. Ross, E. J. The "permeability" hypothesis of the action of insulin. Medicine (Baltimore) 1956, 35, 355.

3. Lukens, F. D. W. The pancreas: Insulin and glucagon. Ann. Rev. Physiol. 1959, 21, 445.

4. Shapiro, B., and Wertheimer, E. The metabolic activity of adipose tissue-A review. Metabolism 1956, 5, 79.

5. Levine, R., and Fritz, I. B. The relation of insulin to liver metabolism. Diabetes 1956, 5, 209.

6. Tarding, F., and Schambye, P. The action of sulphonylureas and insulin on the glucose output from the liver of normal dogs. Endokrinologie 1958, 36, 222.

7. Wall, J. S., Steele, R., de Bodo, R. C., and Altszuler, $\mathrm{N}$. Effect of insulin on utilization and production of circulating glucose. Amer. J. Physiol. 1957, 189, 43.

8. Steele, R. Use of $\mathrm{C}^{14}$-glucose to measure hepatic glucose production following an intravenous glucose load or after injection of insulin. Metabolism 1959, 8, 512.

9. de Bodo, R. C., Steele, R., Altszuler, N., Dunn, A., Armstrong, D. T., and Bishop, J. S. Further studies on the mechanism of action of insulin. Metabolism 1959, 8, 520.

10. Ashmore, J., Cahill, G. F., Jr., Earle, A. S., and Zottu, S. Studies on the disposition of blood glucose: A comparison of insulin and orinase. Diabetes 1958, 7, 1.

11. Shoemaker, W. C., Mahler, R., and Ashmore, J. The effect of insulin on hepatic glucose metabolism in the unanesthetized dog. Metabolism 1959, 8, 494.

12. Cahill, G. F., Jr., Ashmore, J., Renold, A. E.; and Hastings, A. B. Blood glucose and the liver. Amer. J. Med. 1959, 26, 264.

13. Madison, L. L., and Unger, R. H. The physiologic significance of the secretion of endogenous insulin into the portal circulation. I. Comparison of the effects of glucagon-free insulin administered via the portal vein and via a peripheral vein on the magnitude of hypoglycemia and peripheral glucose utilization. J. clin. Invest. 1958, 37, 631.

14. Madison, L. L., and Unger, R. H. The physiologic significance of the secretion of endogenous insulin into the portal circulation. II. Effect of the rate of administration of glucagon-free insulin on the magnitude of peripheral and hepatic actions. Metabolism. In press.

15. Bouckaert, J. P., and de Duve, C. The action of insulin. Physiol. Rev. 1949, 27, 39.

16. de Duve, C. The hepatic action of insulin. Ciba Found. Coll. Endocr. 1956, 9, 203.
17. Dunn, D. F., Friedmann, B., Maass, A. R., Reichard, G. A., and Weinhouse, S. Effects of insulin on blood glucose entry and removal rates in normal dogs. J. biol. Chem. 1957, 225, 225.

18. Jacobs, G., Reichard, G., Goodman, E. H., Jr., Friedmann, B. A., and Weinhouse, S. Action of insulin and tolbutamide on blood glucose entry and removal. Diabetes 1958, 7, 358.

19. Searle, G. L., Mortimore, G. E., Buckley, R. E., and Reilly, W. A. Plasma glucose turnover in humans as studied with $\mathrm{C}^{\mathbf{1 4}}$ glucose. Influence of insulin and tolbutamide. Diabetes 1959, 8, 167.

20. Soskin, S., Essex, H. E., Herrick, J. F., and Mann, F. C. The mechanism of regulation of the blood sugar by the liver. Amer. J. Physiol. 1938, 124, 558.

21. Cannon, W. B., McIver, M. A., and Bliss, S. W. Studies on conditions of activity in endocrine glands: Sympathetic and adrenalin mechanism for mobilizing sugar in hypoglycemia. Amer. J. Physiol. 1924, 69, 46.

22. Holzbauer, M., and Vogt, M. The concentration of adrenaline in the peripheral blood during insulin hypoglycaemia. Brit. J. Pharmacol. 1954, 9, 249.

23. Gershberg, H., and Long, C. N. H. The activation of adrenal cortex by insulin hypoglycemia (abstract). J. clin. Endocr. 1948, 8, 587.

24. Froesch, R. Die Funktion der Nebennierenrinde in der Insulingegenregulation. Schweiz. med. Wschr. 1955, 85, 121.

25. Foa, P. P., Santamaria, L., Weinstein, H. R., Berger, S., and Smith, J. A. Secretion of hyperglycemicglycogenolytic factor in normal dogs. Amer. J. Physiol. 1952, 171, 32.

26. Foa, P. P., Galansino, G., and Pozza, G. Glucagon, a second pancreatic hormone. Recent Progr. Hormone Res. 1957, 13, 473.

27. Bearn, A. G., Billing, B., and Sherlock, S. The effect of adrenaline and noradrenaline on hepatic blood flow and splanchnic carbohydrate metabolism in man. J. Physiol. 1951, 115, 430.

28. Welt, I. D., Stetten, D., Jr., Ingle, D. J., and Morley, E. H. Effect of cortisone upon rates of glucose production and oxidation in the rat. J. biol. Chem. 1952, 197, 57.

29. Thorn, G. W., Renold, A. E., and Winegrad, A. I. Some effects of adrenal cortical steroids on intermediary metabolism. Brit. med. J. 1957, 2, 1009.

30. Berthet, J. Some aspects of the glucagon problem. Amer. J. Med. 1959, 26, 703.

31. Fisher, B., Russ, C., Selker, R. G., and Fedor, E. J. Observations on liver blood flow: Its relationship to cardiac output in anesthetized and unanesthetized animals. A. M. A. Arch. Surg. 1956, 72, 600.

32. Gilmore, J. P. Effect of anesthesia and hepatic sampling site upon hepatic blood flow. Amer. J. Physiol. 1958, 195, 465. 
33. Bradley, S. E., Ingelfinger, F. J., Bradley, G. P., and Curry, J. J. The estimation of hepatic blood flow in man. J. clin. Invest. 1945, 24, 890.

34. Bradley, S. E., Smythe, C. M., Fitzpatrick, H. F., and Blakemore, A. H. The effect of a portacaval shunt on estimated hepatic blood flow and oxygen uptake in cirrhosis. J. clin. Invest. 1953, 32, 526.

35. Combes, B. Simultaneous estimation of hepatic blood flow in dogs by means of $I^{131}$-labeled Rose Bengal $\left(I^{181} \mathrm{RB}\right)$ and bromsulphalein (BSP). Circulation 1958, 18, 705.

36. Fisher, R. A. Statistical Methods for Research Workers, 11th ed. Edinburgh, Oliver \& Boyd, 1950.

37. Somogyi, M. Determination of blood sugar. J. biol. Chem. 1945, 160, 69.

38. Somogyi, M. Notes on sugar determination. J. biol. Chem. 1952, 195, 19.

39. Marks, P. A., and Bishop, J. S. The glucose metabolism of patients with malignant disease and of normal subjects as studied by means of an intravenous glucose tolerance test. J. clin. Invest. 1957, 36, 254.

40. Searle, G. L., Strisower, E. H., and Chaikoff, I. L. Glucose pool and glucose space in the normal and diabetic dog. Amer. J. Physiol. 1954, 176, 190.

41. Altszuler, N., Steele, R., Wall, J. S., and de Bodo, R. C. Effects of adrenocortical steroids on carbohydrate metabolism in hypophysectomized dogs; studies with $\mathrm{C}^{14}$-labeled glucose. Amer. J. Physiol. 1957, 191, 29.

42. Selkurt, E. E. Comparison of the bromsulphalein method with simultaneous direct hepatic blood flow. Circulat. Res. 1954, 2, 155.

43. Simpson, A. M., and Sapirstein, L. A. The plasma clearance and volume of distribution of rose bengal. Surg. Forum 1954, 5, 366.

44. Werner, A. Y., and Horvath, S. M. Measurement of hepatic blood flow in the dog by the bromsulphalein method. J. clin. Invest. 1952, 31, 433.

45. Hallett, E. B., Holton, G. W., Paterson, J. C. S., and Schilling, J. A. Liver blood flow, hepatic glucose production, and splanchnic oxygen consumption in normal dogs and following Eck fistula. Liver blood flow before and after splenectomy. Surg. Gynec. Obstet. 1952, 95, 401.

46. Lipscomb, A., and Crandall, L. A., Jr. Hepatic blood flow and glucose output in normal unanesthetized dogs. Amer. J. Physiol. 1947, 148, 302.

47. Steele, R., Altszuler, N., Wall, J. S., Dunn, A., and de Bodo, R. C. Influence of adrenalectomy on glu- cose turnover and conversion to $\mathrm{CO}_{2}$ : Studies with $\mathrm{C}^{14}$ glucose in the dog. Amer. J. Physiol. 1959, 196, 221.

48. Stetten, D., Jr. in Symposium on the pituitary-adrenal system and diabetes mellitus. Diabetes 1956, 5, 219.

49. Bondy, P. K., Bloom, W. L., Whitner, V. S., and Farrar, B. W. Studies of the role of the liver in human carbohydrate metabolism by the venous catheter technic. II. Patients with diabetic ketosis, before and after the administration of insulin. J. clin. Invest. 1949, 28, 1126.

50. Bearn, A. G., Billing, B. H., and Sherlock, S. The response of the liver to insulin in normal subjects and in diabetes mellitus: Hepatic vein catheterisation studies. Clin. Sci. 1952, 11, 151.

51. Bearn, A. G., Billing, B. H., and Sherlock, S. Response of the liver to insulin; hepatic vein catheterization studies in man. Ciba Found. Coll. Endocr. 1953, 6, 250.

52. Craig, J. W., Drucker, W. R., Miller, M., Woodward, $\mathrm{H}$., Jr., and Molzahn, V. A comparison of the influence of tolbutamide and small doses of insulin on the splanchnic output and peripheral uptake of glucose in man. Ann. N. Y. Acad. Sci. 1959, 74, 537.

53. Madison, L. L., Combes, B., Unger, R. H., and Kaplan, N. The relationship between the mechanism of action of the sulfonylureas and the secretion of insulin into the portal circulation. Ann. N. Y. Acad. Sci. 1959, 74, 548.

54. Stetten, D., Jr. Comments on the fate of and responses to insulin in the liver. Metabolism 1959, 8, 559.

55. Andres, R., Cader, G., and Zierler, K. L. The quantitatively minor role of carbohydrate in oxidative metabolism by skeletal muscle in intact man in the basal state. Measurements of oxygen and glucose uptake and carbon dioxide and lactate production in the forearm. J. clin. Invest. 1956, 35, 671.

56. Cahill, G. F., Jr., Ashmore, J., Earle, A. S., and Zottu, S. Glucose penetration into the liver. Amer. J. Physiol. 1958, 192, 491.

57. Levine, R., Goldstein, M. S., Huddlestun, B., and Klein, S. P. Action of insulin on the 'permeability' of cells to free hexoses, as studied by its effect on the distribution of galactose. Amer. J. Physiol. 1950, 163, 70.

58. Park, C. R., Reinwein, D., Henderson, M. J., Cadenas, E., and Morgan, H. E. The action of insulin on the transport of glucose through the cell membrane. Amer. J. Med. 1959, 26, 674. 